\begin{tabular}{c|c|c}
\hline \hline & DISEASES OF AQUATIC ORGANISMS \\
Vol. 48: $209-212,2002$ & Dis Aquat Org & Published April 5 \\
\hline \hline
\end{tabular}

\title{
Parasites of wild sea bass Dicentrarchus labrax from Norway
}

\author{
Erik Sterud* \\ National Veterinary Institute, PO Box 8156, Dep., 0033 Oslo, Norway
}

\begin{abstract}
Thirteen wild sea bass from the Oslo fjord in south-eastern Norway were examined for parasites. Nineteen species were found, comprising 5 protozoans, 1 monogenean, 8 digeneans, 1 cestode, 2 nematodes and 2 crustaceans. Based on the similarity to the parasitic fauna of Mediterranean sea bass, it is predicted that sea bass farmers in Northern Europe will experience the same parasite problems as sea bass farmers in warmer regions.
\end{abstract}

KEY WORDS: Aquaculture $\cdot$ Fish farming $\cdot$ Parasitic diseases

Resale or republication not permitted without written consent of the publisher

\section{INTRODUCTION}

Inspired by the success with Atlantic salmon, Salmo salar, the Norwegian fish farming industry has initiated a search for marine fish species with potential for intensive farming. Cod Gadus morhua, halibut Hippoglossus hippoglossus, wolf-fish Anarhichas lupus, and turbot Scophthalmus maximus, are already domesticated. Recently in focus is sea bass Dicentrarchus labrax, for onshore production in tanks supplied with sea water that has been heat-exchanged with industrial effluent (cooling) water. The additional possibility for farming of sea bass in traditional floating net cages in the sea should also be evaluated. During the last decade, sea bass has changed from being a regular summer guest in Norwegian waters to being permanently established. In particular this has been observed in the Oslo fjord, but sea bass are caught with increasing frequency all along the southern coast of Norway. Sporadic catches have even been made as far north as Lyngen $\left(69^{\circ} 45^{\prime} \mathrm{N}\right)$. This suggests that water temperatures that previously might have been considered too low are well tolerated by this species.

The wild population of sea bass in Norwegian waters is a likely reservoir for parasites and other infectious agents that may be transmitted to captive fish. Experi-

*E-mail: erik.sterud@vetinst.no ences with salmon, turbot and halibut have shown that exclusion of infective organisms is difficult even in controlled onshore tank systems. In the present study, the parasitic fauna of wild sea bass from the Oslo fjord was recorded, as a part of evaluating potential threats to farmed sea bass in Norway.

\section{MATERIALS AND METHODS}

Thirteen sea bass weighing from 495 to $2431 \mathrm{~g}$ were caught on rod and line in the inner Oslo fjord in August and September 1999, and May, June and July 2000. The fish were kept alive in the laboratory $(<4 \mathrm{~d})$ until examination. They were killed by a blow to the head, and all external and internal organs were examined for parasites with the aid of a dissection microscope and a phase contrast light microscope. When possible, the number of individuals of each parasite species was determined. Parasites that could not be identified while fresh were preserved in $70 \%$ ethanol or $3.7 \%$ formaldehyde for subsequent examination. Some trematodes were stained with carmine red before identification. Gill filaments from a few fish were fixed in $3 \%$ phosphate buffered glutaraldehyde, routinely processed for scanning electron microscopy and viewed in a JEOL JSM 6400 scanning electron microscope. 
Table 1. List of parasites found on 13 specimens of Dicentrarchus labrax from the Oslo fjord, Norway. Intensity is the number of parasites found on fish (alternatively stated as low). AC: abdominal cavity; F: fins; GF: gill filaments; GI: gastrointestinal tract; MC: mouth cavity; S: skin

\begin{tabular}{|c|c|c|c|}
\hline Parasite species & No. infected & Intensity & Site \\
\hline \multicolumn{4}{|l|}{ Protozoa } \\
\hline Ichthyobodo sp. & 1 & Low & GF \\
\hline Cryptobia sp. & 3 & Low & GF \\
\hline Ciliophora: Trichodinidae & 1 & Low & $\mathrm{S}, \mathrm{F}$ \\
\hline Ciliophora: Scuticociliatida & 2 & Low & $\mathrm{S}, \mathrm{F}$ \\
\hline Ciliophora: Sessilina & 2 & Low & $\mathrm{S}$ \\
\hline \multicolumn{4}{|l|}{ Monogenea } \\
\hline Diplectanum aequans (Wagener, 1857) & 13 & $11-152$ & GF, S \\
\hline \multicolumn{4}{|l|}{ Trematoda } \\
\hline Digenea (metacercariae) & 6 & Low & $\mathrm{S}, \mathrm{F}$ \\
\hline Timoniella imbutiforme (Molin, 1859) & 6 & $1-3$ & GI \\
\hline Timoniella praeterita (Looss, 1901) & 2 & $1-2$ & GI \\
\hline Bucephalus spp. & 7 & $1-50$ & GI \\
\hline Cainocreadium labracis (Dujardin, 1845) & 6 & $1-15$ & GI \\
\hline Derogenes varicus (Müller, 1784) & 10 & $1-7$ & GI \\
\hline Brachyphallus crenatus (Rudolphi, 1802) & 3 & 1 & GI \\
\hline Labratrema minimus (Stossich, 1887) & 2 & $1-40$ & GI \\
\hline \multicolumn{4}{|l|}{ Cestoda } \\
\hline Bothriocephalus sp. (immature) & 7 & $1-15$ & GI \\
\hline \multicolumn{4}{|l|}{ Nematoda } \\
\hline Hysterothylacium aduncum (Rudolphi, 1802) (larvae) & 6 & $1-42$ & GI \\
\hline Anisakis sp. (larvae) & 2 & $1-50$ & GI, AC \\
\hline \multicolumn{4}{|l|}{ Crustacea } \\
\hline Lernanthropus kroyeri van Beneden, 1852 & 2 & $2-4$ & GF \\
\hline Caligus minimus (Otto, 1821) & 2 & $1-2$ & $\mathrm{MC}$ \\
\hline
\end{tabular}

\section{RESULTS}

A total of 19 parasite species were found in the 13 examined sea bass (Table 1). The 5 protozoans found in fresh mucosal smears from the skin and gills of the fish were not identified to species level. Preservation was considered impractical, due to the low numbers of each organism (exemplified by the finding of a single trichodinid ciliate).

The most common parasites were diplectanid monogeneans, occurring at $100 \%$ prevalence. On the basis of morphological characters of the squamodisc and the penis, all were designated Diplectanum aequans. They were commonly aggregated in small clusters of 2 to 4 individuals on the gill filaments. The attachment sites were commonly whitish, thickened and apparently necrotic when observed by light microscopy. Scanning electron microscopy showed loss of lamellae in such filaments (Figs. 1 to 3).

The trematodes were the dominating parasite group with 8 (possibly 9) species present. One unidentified species was present as metacercariae in the skin and fins, and the rest were present as adults in the gastrointestinal tract. With few exceptions, all species were present in low numbers and no signs of a pathological effect of the infections were seen.
The 2 nematode species and the cestode were all found as larval or immature stages. The 2 crustaceans were found on fish caught in June.

\section{DISCUSSION}

Aquaculture conditions, concentrating many hosts within a limited space, favour parasites with direct life cycles. In marine fish this has been shown to apply to Ichthyobodo necator (Urawa et al. 1998), trichodinid ciliates (Moksness et al. 1989, Moksness 1990, Lom 1995, Nilsen 1995, author's pers. obs.) and scuticociliates (Cheung et al. 1980, Dragesco et al. 1995, Cawthorn et al. 1996, Messick \& Small 1996, Munday et al. 1997, Sterud et al. 2000). Although protozoans were found at very low intensities in the present study, their potential as serious skin and gill parasites in farmed sea bass should thus not be underestimated.

Two diplectanid monogeneans are commonly found on sea bass in the Mediterranean: Diplectanum aequans and D. laubieri (González-Lanza et al. 1991). The absence of the latter in the present study may be coincidental or the distribution of this species may be restricted to warmer regions. Both species, and especially $D$. aequans, are considered to be potentially 


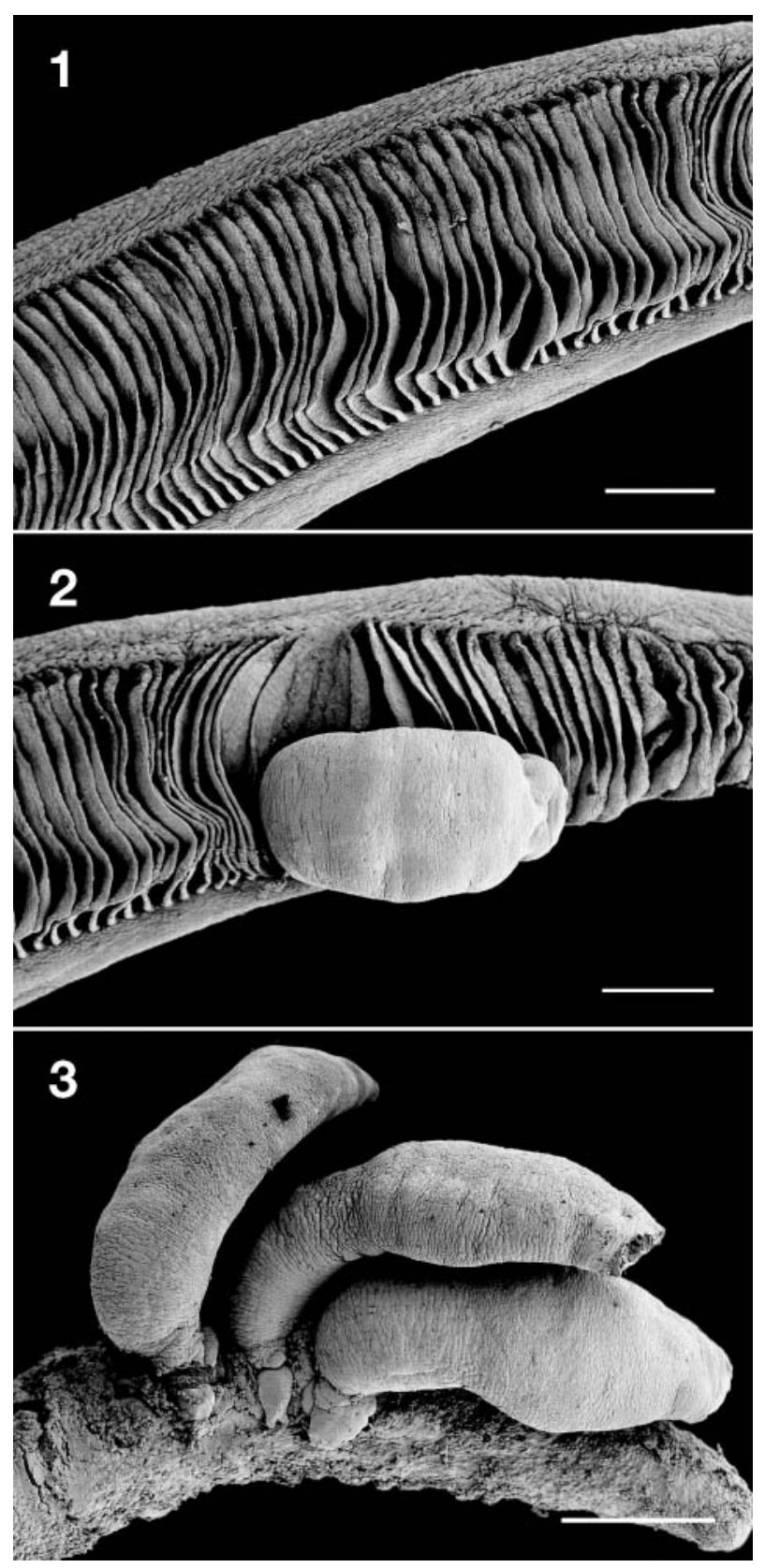

Figs. 1 to 3. Scanning electron micrographs of gills of Dicentrarchus labrax. Scale bars $=0.3 \mathrm{~mm}$. Fig. 1. Normal gill filament and with transverse lamellae. Fig. 2. One individual of Diplectanum aequans parasitising a gill filament. Fig. 3. A cluster of 3 individuals of $D$. aequans parasitising a gill filament. Note loss of the lamellae

harmful in intensive sea bass farming (González-Lanza et al. 1991). The gill damage seen in scanning electron micrographs in the present study confirmed the pathogenic potential of $D$. aequans.

Two of the trematodes found in the present study, Brachyphallus crenatus and Derogenes varicus, are generalists present in a wide range of marine fish spe- cies. Timoniella imbutiforme, T. praeterita, Labratrema minimus and Cainocreadium labracis all use sea bass as a definitive host (Maillard 1976). Bucephalus spp. in Table 1 comprised 2 morphs based on differences in size and number of eggs in the uterus. B. baeri and $B$. labracis, which are both parasites of sea bass, are not distinguished by these features but primarily by their site specificity (Maillard 1976). Unfortunately the digeneans were sampled without paying sufficient attention to their attachment sites within the gastrointestinal tract, and it is not known whether both $B$. baeri and $B$. labracis or only one of them was present. None of the digeneans specific to sea bass have previously been reported from Norway. On the basis of their indirect life cycle, which includes 2 intermediate hosts - a mollusc and a benthic fish (mainly gobies) - digeneans are not likely to be encountered as adults in farmed sea bass. Unless water is taken from the littoral zone or net cages are located in such sites, mass infection of metacercariae in farmed sea bass can probably also be avoided.

The cestode Bothriocephalus sp. and the 2 nematodes Hysterothylacium aduncum and Anisakis sp. were found as immature or larval stages in the sea bass. Fish are infected with these parasites through ingestion of zooplankton intermediate hosts. Anisakis sp. has a considerable pathogenic potential for humans eating raw, infected fish, but is only rarely found in farmed fish in Norway, irrespective of farming technique. Larval stages of $H$. aduncum have caused considerable mortality in fry of halibut fed natural zooplankton (pers. obs.), but as long as commercially available Artemia is preferred for sea bass fry, $H$. aduncum infections can probably be avoided. The possibility for economical losses due to infections with the cestode Bothriocephalus sp. in farmed sea bass can, however, not be excluded, based on its similarity to another pseudophyllidean cestode, Eubothrium crassum. This parasite infects farmed salmon in Norway on a large scale, showing that parasites with indirect life cycles also may cause mass infection in farmed fish. The economic losses caused by this parasite are considered to be large, primarily due to reduced growth of the host fish and medication costs (Bristow \& Berland 1991, Saksvik et al. 2001).

Caligus minimus, which was found in the mouth cavity of 2 sea bass in the present study, should be regarded as a potential problem. Caligid copepods are among the most problematic parasites in cultured marine species, including Mediterranean sea bass and sea bream (Paperna 1980, Rodgers \& Furones 1998). Other examples are Lepeophtheirus salmonis and C. elongatus, which cause severe problems in Scottish, Irish and Norwegian salmon farming (Pike \& Wodsworth 2000). The preferred site of infection for $C$. minimus creates an additional problem. Cleaner fish such as goldsinny wrasse Cteno- 
labrus rupestris are used in Norwegian fish farms to effectively 'de-louse' farmed salmon parasitised by the skin parasites L. salmonis and C. elongatus. However, the sheltered location inside the mouth cavity of the host makes such treatment of $C$. minimus infections in sea bass impossible. Apart from C. minimus one cannot exclude $C$. elongatus from the list of potential threats to farmed sea bass. Although it was not found in the present study, this species has been reported from more than 80 fish species, including farmed striped bass Morone saxatilis (Hogans 1994), and thus presents a threat to almost any farmed marine fish.

Endoparasitic protozoans and myxosporidians were not found in the present study. Several species in both these groups have been reported from sea bass in the Mediterranean area (Sitjà-Bobadilla \& AlvarezPellitero 1990, Alvarez-Pellitero \& Sitjà-Bobadilla 1993, Alvarez-Pellitero et al. 1993, Santos 1996). Some, however, had a low prevalence and this may explain their absence in a restricted material such as in the present study. It would indeed be surprising if members of these groups were not present in sea bass along the Norwegian coast. Alvarez-Pellitero and colleagues stressed the pathological potential of Ceratomyxa spp. and Sphaerospora testicularis, which even seemed to be favoured by culture conditions (Alvarez-Pellitero \& Sitjà-Bobadilla 1993, Alvarez-Pellitero et al. 1993).

Despite a restricted material, 19 parasite species were found in the wild sea bass from Norway. Some species reported from the Mediterranean area were not found. Nonetheless, the parasite fauna of sea bass from Northern Europe is probably very similar to that from Southern Europe. It is therefore expected that parasitic diseases that are problematic for Mediterranean sea bass farming may also occur at higher latitudes.

Acknowledgements. The sea bass proved to be hard to catch, and Dr. Trygve Poppe, Dr. Tor Atle Mo and Per Christian Mortensen are all thanked for never losing their fighting spirit and hope after early morning fights with hundreds of mackerel, Scomber scombrus.

\section{LITERATURE CITED}

Alvarez-Pellitero P, Sitjà-Bobadilla A (1993) Ceratomyxa spp. (Protozoa: Myxosporea) infections in wild and cultured sea bass, Dicentrarchus labrax (L.), from the Spanish Mediterranean area: population dynamics and histopathology. J Fish Biol 42:889-901

Alvarez-Pellitero P, Sitjà-Bobadilla A, Franco-Sierra (1993) Protozoan parasites of wild and cultured sea bass, Dicentrarchus labrax (L.), from the Mediterranean area. Aquac Fish Manage 24:101-108

Bristow GA, Berland B (1991) The effect of long term, low level Eubothrium sp. (Cestoda: Pseudophyllidea) infection on growth in farmed salmon (Salmo salar L.). Aquaculture 98:325-330

Cawthorn RJ, Lynn DH, Despres B, MacMillan R, Maloney R,
Loughlin M, Bayer R (1996) Description of Anophryoides haemophila n. sp. (Scuticociliatida: Orchithophryidae), a pathogen of American lobsters Homarus americanus. Dis Aquat Org 24:143-148

Cheung PJ, Nigrelli RF, Ruggieri GD (1980) Studies on the morphology of Uronema marinum Dujardin (Ciliatea: Uronematidae) with a description of the histopathology of the infection in marine fishes. J Fish Dis 3:295-303

Dragesco A, Dragesco J, Coste F, Gasc C, Romestand B, Raymond J, Bouix G (1995) Philasterides dicentrarchi, n. sp., (Ciliophora, Scuticociliatida), a histophagous opportunistic parasite of Dicentrarchus labrax (Linnaeus, 1758), a reared marine fish. Eur J Protistol 31:327-340

González-Lanza C, Alvarez-Pellitero P, Sitjá-Bobadilla A (1991) Diplectanidae (Monogenea) infestations of sea bass, Dicentrarchus labrax (L.), from the Spanish Mediterranean area. Parasitol Res 77:307-314

Hogans WE (1994) Cage culture of striped bass in marine waters of the lower Bay of Fundy. Prog Fish-Cult 56:255-257

Lom J (1995) Trichodinidae and other ciliates (Phylum Ciliophora). In: Woo PTK (ed) Fish diseases and disorders, Vol 1, Protozoan and metazoan infections. CAB International, Wallingford, p 229-262

Maillard C (1976) Distomatoses de poissons en millieu lagunaire. Thèse Docteur ès sciences naturelles, Académie de Montpellier, p 1-383

Messick GA, Small EB (1996) Mesanophrys chesapeakensis $\mathrm{n}$. sp., a histophagous ciliate in the blue crab, Callinectes sapidus, and associated histopathology. Invertebr Biol 115: $1-12$

Moksness E (1990) Weaning of wild-caught common wolffish (Anarhichas lupus) larvae. Aquaculture 91:77-85

Moksness E, Gjøsæter J, Reinert A, Fjallstein IS (1989) Startfeeding and on-growing of wolffish (Anarhichas lupus) in the laboratory. Aquaculture 77:221-228

Munday BL, O'Donoghue PJ, Watts M, Rough K, Hawkesford $\mathrm{T}$ (1997) Fatal encephalitis due to the scuticociliate Uronema nigricans in sea-caged, southern bluefin tuna Thunnus maccoyii. Dis Aquat Org 30:17-25

Nilsen F (1995) Description of Trichodina hippoglossi n. sp. from farmed Atlantic halibut larvae Hippoglossus hippoglossus. Dis Aquat Org 21:209-214

Paperna I (1980) study of Caligus minimus (Otto, 1821), (Caligidae Copepoda) infections of the sea bass Dicentrarchus labrax (L.) in Bardawil lagoon. Ann Parasitol 55:687-706

Pike AW, Wodsworth SL (2000) Sealice on salmonids: their biology and control. In: Baker JR, Muller R, Rollinson D (eds) Advances in parasitology, Vol 44. Academic Press, San Diego, p 234-318

Rodgers CJ, Furones MD (1998) Disease problems in cultured marine fish in the Mediterranean. Fish Pathol 33:157-164

Saksvik M, Nilsen F, Nylund A, Berland B (2001) Effect of marine Eubothrium sp (Cestoda : Pseudophyllidea) on the growth of Atlantic salmon, Salmo salar L. J Fish Dis 24: 111-119

Santos MJ (1996) Observations on the parasitofauna of wild sea bass (Dicentrarchus labrax L.) from Portugal. Bull Eur Assoc Fish Pathol 16:77-79

Sitjà-Bobadilla A, Alvarez-Pellitero P (1990) Sphaerospora testicularis sp. nov. (Myxosporea: Sphaerosporidae) in wild and cultured sea bass, Dicentrarchus labrax (L.), from the Spanish Mediterranean area. J Fish Dis 13:193-203

Sterud E, Hansen MK, Mo TA (2000) Systemic infection with Uronema-like ciliates in farmed turbot, Scophthalmus maximus (L.). J Fish Dis 23:33-37

Urawa S, Ueki N, Karlsbakk E (1998) A review of Ichthyobodo infection in marine fishes. Fish Pathol 33:311-320 